\title{
Implementation of Data Mining to Predict Food Sales Rate Method using Apriori
}

\author{
Yuli Nur Indah Sari \\ Faculty of Information and \\ Communication Technology \\ National University
}

\author{
Agung Triayudi \\ Faculty of Information and \\ Communication Technology \\ National University
}

\author{
Ira Diana Sholihati \\ Faculty of Information and \\ Communication Technology \\ National University
}

\begin{abstract}
Fonzu Premium restaurant management has had difficulty in knowing the which menus are most in demand by consumers and still uses manual methods, and sometimes customers can not order the desired order Because some of the menus on the menu list are up or some raw material supplies are not available. Apriori algorithm is one algorithm that searches frequent itemset by using the association rule technique. Based on the results of implementing the association rule method using a priori algorithm to find the linkages between the level of sales menu Fonzu Premium ordered at restaurants. With this association rule, it is expected to help the managerial parties to find out the which menus are most in demand by consumers, so a system can be used the which can be used as a prediction system using data mining association rule Apriori algorithm using.
\end{abstract}

\section{Keywords}

Apriori, Association Rules, Data Mining

\section{INTRODUCTION}

Restaurants are located in the area Premium Fonzu Sudirman in Central Jakarta has become one Japanese restaurant that serves a main menu of Japanese food. Restaurants Near the office environment is always filled with customers, ranging from office workers to the Japanese people. During this time the management difficulties in knowing the menu most in demand by consumers and still use manual, and sometimes customers can not order the desired order for some menu contained in the menu list has been exhausted or some lack of raw material inventory. By predicting sales can help the restaurant management in increasing sales and sales transaction data can be processed by using Apriori algorithm to produce information in the form of food sales predictions.

Apriori algorithm is an algorithm data retrieval associative rules to determine the associative relationship of a combination of items [1]. Apriori algorithm is an algorithm that is very famous to find a high frequency pattern. High frequency pattern is a pattern item in a database that has a frequency or support above a certain threshold called the minimum support. This high frequency pattern used to draw up the rules associative and also some other data mining techniques. The most popular algorithm known as Apriori to generate and test paradigm, namely the manufacture of candidate combinations of items that may be based on certain rules and then tested whether a combination of these items qualify minimum support [2].

Several previous studies had done before them by Ristianigrum, Sulastri about the implementation of data mining algorithms Apriori defpngan proceeds are used to help AHASS Akmal Jaya Motor in determining the spare parts any product that must be purchased by Akmal Jaya Motor. Data preparation but requires longer to be more mature in its processing [3]. The other study was conducted by Kennedi Tampubolon, Hoga Saragih, Bobby Reza about the implementation of data mining algorithms Apriori on inventory system health tools with results can implement Apriori algorithm to accelerate the process of formation tendency combination pattern itemset proceeds from the sale of medical equipment in the pharmacy Kelambir-2 Field. However, there are still weaknesses because they have to scan the database each time iteration, so for very large databases take a long time [4]. Based on two studies, it is known as a reference to the restaurants Fonzu Premium to predict the outcome of the sale of food based on the data of previous transactions, the data is processed using Apriori algorithm which is a form of data mining algorithms that will provide information about the relationship between items in the database that can be used widely in business processes especially in the process to predict the result of the sale of food. The data analysis is done by creating an application that helps the restaurant in acquiring knowledge in the form of patterns of food sales transaction within a certain period of months.

By performing data analysis company and want to know the number of food and beverage sales, existing sales data to be processed or analyzed to determine the level of consumer trends in each product on an interest factor. From the data processing will be obtained a product consumption pattern of the food sales [4].

This research was conducted by using the sales transaction data for one month the month of June 2018 at the Spanish Fonzu Premium. The results obtained are linkages between the three combinations menu. The purpose of this research is to implement methods of association rules using Apriori algorithm to find linkages level of sales were booked in the restaurant menu Fonzu Premium. With association rules is expected to help the managerial order to know what the menu is the most demanding consumers.

\section{RESEARCH METHODS}

Apriori algorithm using attribute frequency knowledge previously known to process more information. At Apriori algorithm determines the candidate may emerge by looking at the minimum support and minimum confidence. Support is supporting value or percentage combination of an item in the database [5].

The steps in determining the rules of association of this study can be described in the following flowchart: 


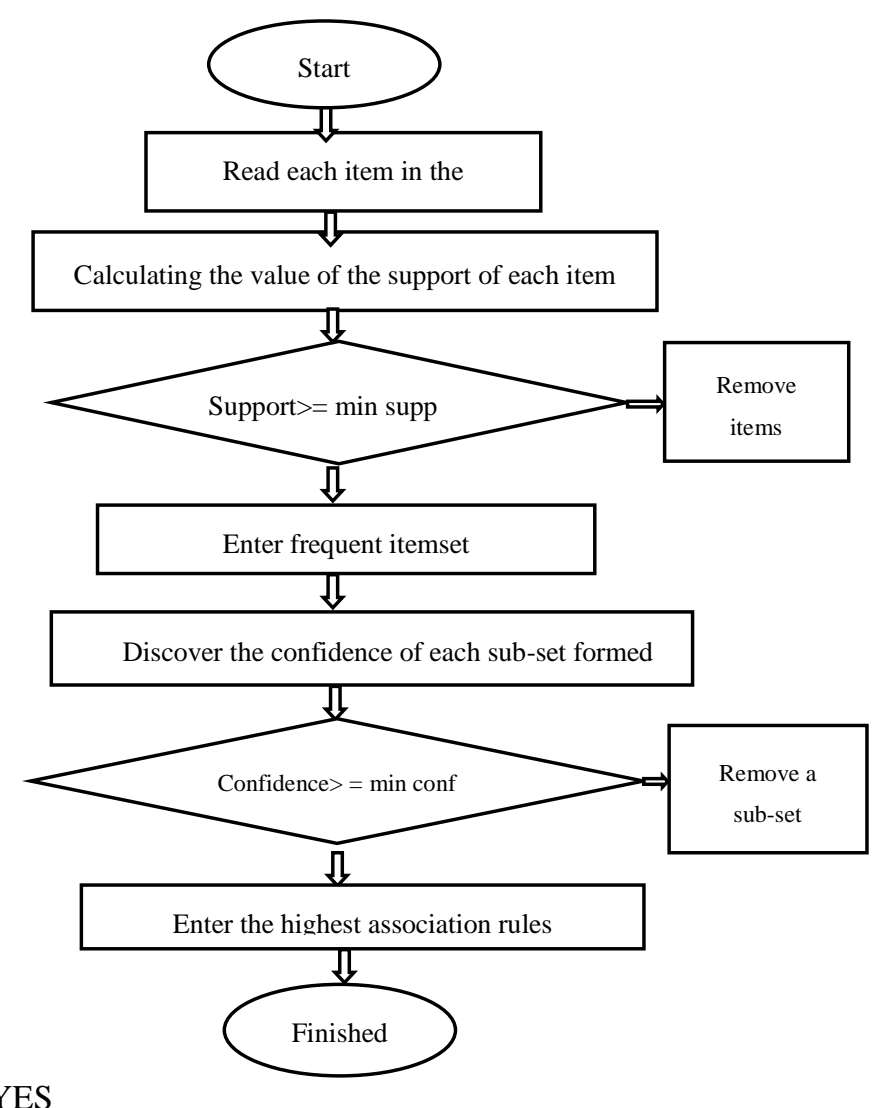

Figure 1. Flowchart Apriori

\section{Analysis Calculation Algorithm Apriori}

Apriori algorithm is an algorithm that is often used to find a link between the item with other items and high frequency pattern. Apriori algorithm is divided into several stages called iterations:

1. Determining minimum support

2. Formation candidate itemset, candidate k-itemset is formed from a combination of (k-1) -itemset obtained from the previous iteration. One characteristic of Apriori algorithm is the trimming candidate k-itemset subsetnya containing k-1 items are not included in the high frequency pattern with a length of $\mathrm{k}-1$.

3. The calculation of the support of each candidate kitemset. Support of each candidate k-itemsets obtained by scanning a database to calculate the number of transactions that contain all the items within the candidate k-itemset. It is also a characteristic of Apriori algorithm in which the necessary calculations to scan the entire database as k-itemset longest.

4. Set a high frequency pattern. High frequency pattern that includes the k-k-itemset item or set of candidate kitemset

5. Make the process for the next iteration until no k-itemset meet the minimum support [2].

Association rule is one of the main techniques or procedures in Market Basket Analysis to find relationships between items in a data set and display in the form of association rules. Terms of the rules of the association must meet the minimum number of occurrences in the total data, the minimum number of occurrences is called the minimum support count. The value of the specified minimum support from the researchers themselves. His example specified minimum support count value of 15 with a total of 30 transactions the miminum value of its support is $15 / 30 * 100 \%=50 \%$ so was equal to the value of his confidence. In the next stage of the search performed support value on each item. Support here means the number of transactions in the database that contains the item. Support search formula can be seen from the equation [1][2][6] as follows:

Support formula is as follows:

Support $(\mathbf{A})=$

Jumlah Transaksi Mengandung A Total Transaksi

Meanwhile, when looking for value the support of two items:

Support $(\mathrm{A}, \mathrm{B})=$

$\frac{\text { Jumlah Transaksi Mengandung A dan B }}{\text { Total Transaksi }} * 100 \%$

While confidence is a confidence value that the strong relationship between items in a Apriori. Confidence can be sought after the emergence of a frequency pattern found items

Confidence the following formula:

confidence $=\mathbf{P}(\mathbf{B} \mid \mathbf{A})=$

$\frac{\text { Jumlah Transaksi Mengandung A dan B }}{\text { Jumlah Transaksi Mengandung A }} * 100 \%$

Results obtained from this study is to determine the pattern of the combination of high frequency itemsets (frequent patternt) is the highest gain support and confidence and database obtained with Microsoft Excel.

Steps rationale of this study can be described in the following flowchart:

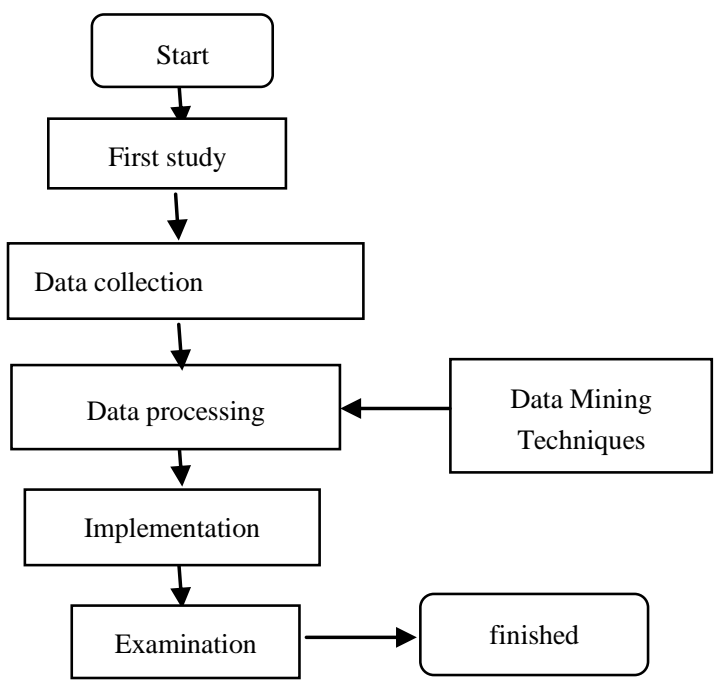

Figure 2. Flowchart Research

\section{Description Flowchart Research}

Here's a step - step of flowcharts research to be made a) First study

The initial step of this research is to find and study the issues to be examined. Then determine the scope of the problem, the background of the problem, and learn some of the literature relating to the cases and how to find solutions to these problems. To achieve the goals to be determined, it is necessary to learn some of the literature used. Then studied 
literature were selected for the literature can be determined which will be used in research. Through the study of literature, studied the theories related to data mining, association rules, as well as Apriori algorithm that will be discussed.

\section{b) Data Collection}

The method used in the process of collecting data in this study are the interviews necessary to inquire directly about any problems that are often faced by Fonzu Premium particular about what the menu is the most demanding consumers and documentation is done to find data on things or variable in the form of a file or document. In this case the author conducted data collection for use as an ingredient implementation.

\section{c) Data Processing}

In the first stage of data processing to identify the problems that exist and often faced by Fonzu Premium, for kemudiaan describe the problems to obtain a solution. Furthermore, the authors use data mining techniques with Apriori algorithm to obtain the results as a goal to be achieved by researchers who could then serve as a Premium Fonzu the knowledge in increasing sales.

\section{d) Implementation}

At this stage to facilitate the author in the proof of the results of the analysis, the authors used a data mining tools or applications that already exist. While the database is used to store data that is using a Microsoft Excel database.

\section{e) Examination}

At this stage, the authors tested by using data mining tools or applications by connecting to a database that has been filled or contains data that will be tested.

\section{RESULTS AND DISCUSSION}

The data used is the sales transaction data Fonzu Premium restaurant in June 2018. In Table 1 is part of a collection of the sales transaction in June 2018.

Table 1. Sample Data Month June 2018

\begin{tabular}{|c|c|c|c|c|c|c|}
\hline $\begin{array}{c}\text { date of } \\
\text { Transacti } \\
\text { on }\end{array}$ & $\begin{array}{c}\text { Gyo } \\
\text { za }\end{array}$ & $\begin{array}{c}\text { Tori } \\
\text { kara } \\
\text { ge }\end{array}$ & $\begin{array}{l}\text { Chick } \\
\text { en } \\
\text { Teriya } \\
\text { ki Don }\end{array}$ & $\begin{array}{l}\text { Saikoro } \\
\text { Yakime } \\
\text { shi }\end{array}$ & $\begin{array}{l}\text { Us } \\
\text { Be } \\
\text { ef } \\
\text { Set }\end{array}$ & $\begin{array}{c}\text { Fish } \\
\text { And } \\
\text { Chi } \\
\text { ps }\end{array}$ \\
\hline $\begin{array}{c}01-06- \\
2018\end{array}$ & 5 & 2 & 3 & - & - & 2 \\
\hline $\begin{array}{c}\text { 02-06- } \\
2018\end{array}$ & 2 & 4 & 2 & 2 & 1 & - \\
\hline $\begin{array}{c}03-06- \\
2018\end{array}$ & 7 & - & 4 & 4 & 3 & - \\
\hline $\begin{array}{c}\text { 04-06- } \\
2018\end{array}$ & 1 & 1 & 5 & 1 & - & 1 \\
\hline $\begin{array}{c}\text { 05-06- } \\
2018\end{array}$ & 1 & 1 & - & - & - & 3 \\
\hline$\ldots$ & $\ldots$ & $\ldots$ & $\ldots$ & $\ldots$ & $\ldots$ & $\ldots$ \\
\hline $\begin{array}{c}29-06- \\
2018\end{array}$ & 2 & - & 3 & 3 & 2 & - \\
\hline $\begin{array}{c}30-06- \\
2018\end{array}$ & 6 & - & 3 & 1 & 6 & - \\
\hline
\end{tabular}

Can be seen from the above table shows the title line and the next line item group is the number of sales transactions. Samples above data used as an example in using the association rule Apriori algorithm. The next steps to be able to enter data on the form RapidMiner format then converted into a numerical binomial format which contains the digits 1 to the sales transaction and the number 0 for the transaction without the sale, so that it becomes like to see in table 2 .

Table 2. Transaction Sales in binomial format

\begin{tabular}{|c|c|c|c|c|c|c|}
\hline $\begin{array}{c}\text { Serial } \\
\text { numb } \\
\text { er }\end{array}$ & $\begin{array}{c}\text { Gyoz } \\
\text { a }\end{array}$ & $\begin{array}{c}\text { Tori } \\
\text { karag } \\
\mathrm{e}\end{array}$ & $\begin{array}{c}\text { Chicke } \\
\mathrm{n} \\
\text { Teriya } \\
\text { ki Don }\end{array}$ & $\begin{array}{c}\text { Saikoro } \\
\text { Yakimes } \\
\text { hi }\end{array}$ & $\begin{array}{c}\text { Us } \\
\text { Bee } \\
\mathrm{f} \\
\text { Set }\end{array}$ & $\begin{array}{c}\text { Fish } \\
\text { And } \\
\text { Chip } \\
\mathrm{s}\end{array}$ \\
\hline 1 & 1 & 1 & 1 & 0 & 0 & 1 \\
\hline 2 & 1 & 1 & 1 & 1 & 1 & 0 \\
\hline 3 & 1 & 0 & 1 & 1 & 1 & 0 \\
\hline 4 & 1 & 1 & 1 & 0 & 0 & 1 \\
\hline 5 & 1 & 1 & 0 & 0 & 0 & 1 \\
\hline$\cdots$ & $\cdots$ & $\cdots$ & $\cdots$ & $\cdots$ & $\cdots$ & $\cdots$ \\
\hline 29 & 1 & 0 & 1 & 1 & 1 & 0 \\
\hline 30 & 1 & 0 & 1 & 1 & 0 & 0 \\
\hline
\end{tabular}

Shown in table 2 the results of the numerical format to format conversion binomial, number 1 for the sales transaction numbers from 0 to transactions without sales.At this stage, the search support value on each item. Support here means the number of transactions in the database that contains the item.Here's how the settlement of the case study above using Apriori algorithm:

a) formation itemset

Of format support table 2 can be calculated from the combined category or categories by adding the transaction containing that category divided by the total number of transactions, which can be broken down into the following table:

Table 3. Support of each item

\begin{tabular}{|c|c|c|}
\hline item & total & Support \\
\hline Gyoza & 27 & $90 \%$ \\
\hline Tori karage & 13 & $43 \%$ \\
\hline Chicken Teriyaki Don & 25 & $83 \%$ \\
\hline Saikoro Yakimeshi & 23 & $76 \%$ \\
\hline Us Beef Set & 19 & $63 \%$ \\
\hline Fish And Chips & 12 & $40 \%$ \\
\hline
\end{tabular}

In Table 3 support which has a threshold of more than 50\%, there are four categories: Gyoza, Chicken Teriyaki Don, Saikoro Yakimeshi and Us Beef Set.

b) Combination 2 itemset

The process of formation of $\mathrm{C} 2$ or called with two itemsets with the minimum amount of support $=50 \%$ can be described in table 4. Establishment combination is obtained by mounting one item to another. Create a couple of items starting from the 
first item and then proceed to the second item.

Table 4. Combination 2 itemset

\begin{tabular}{|c|c|c|}
\hline Category & total & Support \\
\hline Gyoza, Tori karage & 12 & $40 \%$ \\
\hline Gyoza, Chicken Teriyaki Don & 24 & $80 \%$ \\
\hline Gyoza, Saikoro Yakimeshi & 20 & $67 \%$ \\
\hline Gyoza, Us Beef Set & 17 & $57 \%$ \\
\hline Gyoza, Fish And Chips & 11 & $37 \%$ \\
\hline Tori karage, Chicken Teriyaki Don & 10 & $33 \%$ \\
\hline Tori karage, Saikoro Yakimeshi & 10 & $33 \%$ \\
\hline Tori karage, Us Beef Set & 8 & $37 \%$ \\
\hline Tori karage, Fish And Chips & 7 & $23 \%$ \\
\hline Chicken Teriyaki Don, Saikoro Yakimeshi & 21 & $70 \%$ \\
\hline Chicken Teriyaki Don, Us Beef Set & 16 & $53 \%$ \\
\hline Chicken Teriyaki, Fish And Chips & 11 & $37 \%$ \\
\hline Saikoro Yakimeshi, Us Beef Set & 16 & $53 \%$ \\
\hline Saikoro Yakimeshi, Fish And Chips & 10 & $33 \%$ \\
\hline Us Beef Set, Fish And Chips & 8 & $27 \%$ \\
\hline
\end{tabular}

In Table 4 support which exceeds the threshold of $50 \%$ there are six categories, namely Gyoza and Chicken Teriyaki Don, Gyoza and Saikoro Yakimeshi, Gyoza and Us Beef Set, Chicken Teriyaki Don and Saikoro Yakimeshi, Chicken Teriyaki Don and Us Beef Set, Saikoro Yakimeshi and Us Beef Set.

Formation with 3 itemset or 3 combinations of items can be described in table 5 .

Table 5. Support of the combination of three categories

\begin{tabular}{|c|c|c|}
\hline Category & total & Support \\
\hline Gyoza, Tori karage, Chicken Teriyaki Don & 10 & $33 \%$ \\
\hline Gyoza, Tori karage, Saikoro Yakimeshi & 9 & $30 \%$ \\
\hline Gyoza, Tori karage, Us Beef Set & 7 & $23 \%$ \\
\hline Gyoza, Tori karage, Fish And Chips & 7 & $23 \%$ \\
\hline $\begin{array}{c}\text { Gyoza, Chicken Teriyaki Don, Saikoro } \\
\text { Yakimeshi }\end{array}$ & 20 & $67 \%$ \\
\hline $\begin{array}{c}\text { Gyoza, Chicken Teriyaki Don, Us Beef set } \\
\text { Chips }\end{array}$ & 16 & $53 \%$ \\
\hline $\begin{array}{c}\text { Gyoza, Chicken Teriyaki Don, Fish And } \\
\text { Gyoza, Saikoro Yakimeshi, Us Beef Set }\end{array}$ & 10 & $33 \%$ \\
\hline $\begin{array}{c}\text { Gyoza, Saikoro Yakimeshi, Fish And Chips } \\
\text { Saikoro Yakimeshi, Chicken Teriyaki Don, } \\
\text { Us Beef Set }\end{array}$ & 15 & $30 \%$ \\
\hline
\end{tabular}

From Table 5, the combined data from the three categories that meet the threshold of more than 50\%, there are 3 data that Gyoza + Chicken Teriyaki Don + Saikoro Yakimeshi, Gyoza + Chicken Teriyaki Don + Us Beef Set, Saikoro + Chicken
Teriyaki Don + Us Beef Set ,

c) formation of Association

The next step after determining the support from the combination of the category is to calculate the confidence to find the association rules. For the formation of the association refers to the combination of 3 itemset exceeds the threshold of $50 \%$. By using the formula of calculation confidence, then obtained the data as shown in Table 6 .

Table 6. Confidence 3 items

\begin{tabular}{|c|c|c|c|}
\hline Category & total & Support & confidence \\
\hline $\begin{array}{c}\text { Gyoza, Chicken } \\
\text { Teriyaki Don, Saikoro } \\
\text { Yakimeshi }\end{array}$ & $20 / 27$ & $67 \%$ & $74 \%$ \\
\hline $\begin{array}{c}\text { Gyoza, Chicken } \\
\text { Teriyaki Don, Us Beef } \\
\text { Set }\end{array}$ & $16 / 27$ & $53 \%$ & $59 \%$ \\
\hline $\begin{array}{c}\text { Saikoro, Chicken } \\
\text { Teriyaki Don, Us Beef } \\
\text { Set }\end{array}$ & $15 / 23$ & $50 \%$ & $65 \%$ \\
\hline
\end{tabular}

From Table 6 it can be seen that the association rules that form that there are three rules that can be used as a reference to make and know the rules associated with the highest confidence value.

Having in mind the confidence value of 3 items formed the next step make the final association rules and determine the highest confidence score of each combination described in Table 7 below. For the formation of the set of item association rules that have been obtained will be formed into a pattern of "if $\mathrm{X}$, then $\mathrm{Y}$ ".

Table 7. Association Rules

\begin{tabular}{|c|c|c|c|}
\hline Category (X => Y) & $\begin{array}{c}\text { Support } \\
\text { XUY }\end{array}$ & $\begin{array}{c}\text { Support } \\
\text { X }\end{array}$ & conf \\
\hline $\begin{array}{c}\text { Gyoza, Chicken Teriyaki Don } \\
\text { => Saikoro Yakimeshi }\end{array}$ & $67 \%$ & $80 \%$ & $83 \%$ \\
\hline $\begin{array}{c}\text { Gyoza => Chicken Teriyaki } \\
\text { Don, Saikoro Yakimeshi }\end{array}$ & $67 \%$ & $90 \%$ & $74 \%$ \\
\hline $\begin{array}{c}\text { Chicken Teriyaki Don, } \\
\text { Saikoro Yakimeshi => Gyoza }\end{array}$ & $67 \%$ & $70 \%$ & $95 \%$ \\
\hline $\begin{array}{c}\text { Chicken Teriyaki Don => } \\
\text { Saikoro Yakimeshi, Gyoza }\end{array}$ & $67 \%$ & $83 \%$ & $80 \%$ \\
\hline $\begin{array}{c}\text { Saikoro Yakimeshi, Gyoza } \\
\text { => Chicken Teriyaki Don }\end{array}$ & $67 \%$ & $67 \%$ & $100 \%$ \\
\hline $\begin{array}{c}\text { Saikoro Yakimeshi => } \\
\text { Chicken Teriyaki Don, Gyoza }\end{array}$ & $67 \%$ & $76 \%$ & $86 \%$ \\
\hline $\begin{array}{c}\text { Gyoza => Set Us Beef, } \\
\text { Chicken Teriyaki Don }\end{array}$ & $53 \%$ & $90 \%$ & $59 \%$ \\
\hline $\begin{array}{c}\text { Gyoza, Chicken Teriyaki Don } \\
\text { => Us Beef Set }\end{array}$ & $53 \%$ & $80 \%$ & $66 \%$ \\
\hline $\begin{array}{c}\text { Us Beef Set => Gyoza, } \\
\text { Chicken Teriyaki Don }\end{array}$ & $53 \%$ & $63 \%$ & $84 \%$ \\
\hline $\begin{array}{c}\text { Us Beef Set, Gyoza => } \\
\text { Chicken Teriyaki Don }\end{array}$ & $53 \%$ & $57 \%$ & $94 \%$ \\
\hline
\end{tabular}




\begin{tabular}{|c|c|c|c|}
\hline $\begin{array}{c}\text { Chicken Teriyaki Don => Us } \\
\text { Beef Set, Gyoza }\end{array}$ & $53 \%$ & $83 \%$ & $64 \%$ \\
\hline $\begin{array}{c}\text { Chicken Teriyaki Don, Us } \\
\text { Beef Set => Gyoza }\end{array}$ & $53 \%$ & $57 \%$ & $94 \%$ \\
\hline $\begin{array}{c}\text { Saikoro Yakimeshi => } \\
\text { Chicken Teriyaki Don, Us } \\
\text { Beef Set }\end{array}$ & $50 \%$ & $76 \%$ & $65 \%$ \\
\hline $\begin{array}{c}\text { Saikoro Yakimeshi, Chicken } \\
\text { Teriyaki Don => Us Beef Set }\end{array}$ & $50 \%$ & $70 \%$ & $71 \%$ \\
\hline $\begin{array}{c}\text { Chicken Teriyaki Don => } \\
\text { Saikoro Yakimeshi, Us Beef } \\
\text { Set }\end{array}$ & $50 \%$ & $83 \%$ & $60 \%$ \\
\hline $\begin{array}{c}\text { Chicken Teriyaki Don, Us } \\
\text { Beef Set => Saikoro } \\
\text { Yakimeshi }\end{array}$ & $50 \%$ & $57 \%$ & $88 \%$ \\
\hline $\begin{array}{c}\text { Us Beef Set => Saikoro } \\
\text { Yakimeshi, Chicken Teriyaki } \\
\text { Don }\end{array}$ & $50 \%$ & $63 \%$ & $78 \%$ \\
\hline $\begin{array}{c}\text { Us Beef Set, Saikoro } \\
\text { Yakimeshi => Chicken } \\
\text { Teriyaki Don }\end{array}$ & $50 \%$ & $53 \%$ & $93 \%$ \\
\hline Accorng the table 7, the fing & & & \\
\hline
\end{tabular}

According to the table 7, the final result of the formation of the association rules, namely with the highest confidence score of $100 \%$ Saikoro Yakimeshi, Gyoza $\Rightarrow$ Chicken Teriyaki Don.

Simulations are also performed using the software RapidMiner which can be seen in Figure 3, below.

\section{AssociationRules}

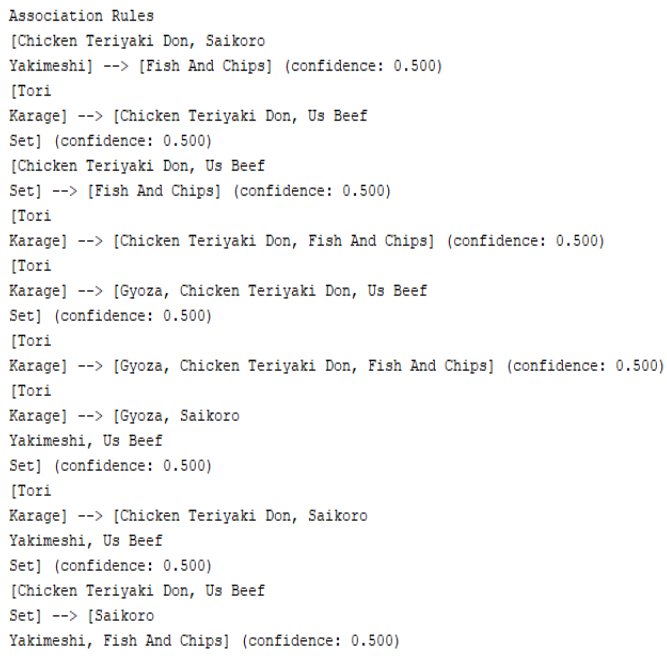

Figure 3. Association Rules of RapidMiner

By knowing the predictive results meal menu most sold it, so that it can provide information to the managerial predict the food menu in demand by consumers and can also be used to plan the stock material to come.

Here are the results of testing using applications that can be described in Figure 4 below

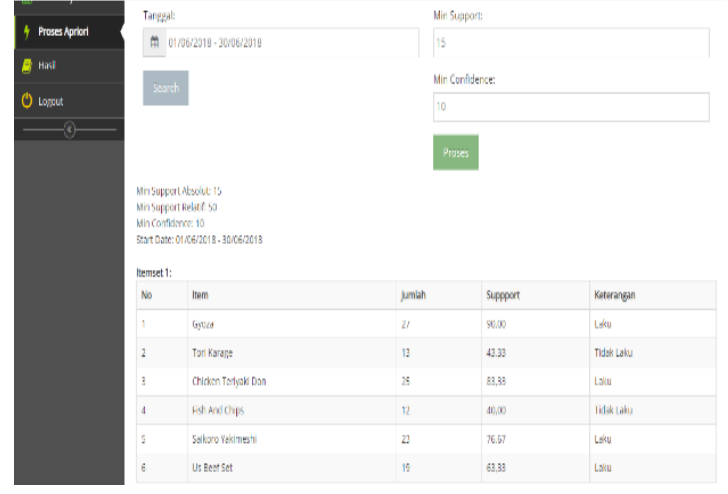

Figure 4.

Seen from Figure 4 the results of the application by entering the value of the support 15 and 10 mengasilkan confidence salable item No 4 with values above 50\%, namely support Gyoza, Chicken Teriyaki Don, Saikoro Yakimeshi and Us Beef set.

Furthermore, the process of formation of a combination of two items can be seen in Figure 5.

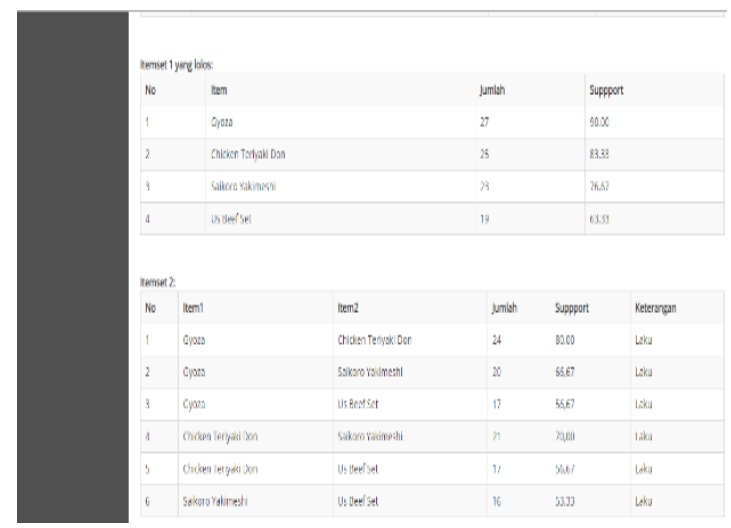

Figure 5.

Can be seen in Figure 5 support that exceed the threshold of $50 \%$ there are six categories, namely Gyoza and Chicken Teriyaki Don, Gyoza and Saikoro Yakimeshi, Gyoza and Us Beef Set, Chicken Teriyaki Don and Saikoro Yakimeshi, Chicken Teriyaki Don and Us Beef Set, Saikoro Yakimeshi and Us Beef Set.

After that the process of formation of a combination of three items can be seen in Figure 6.

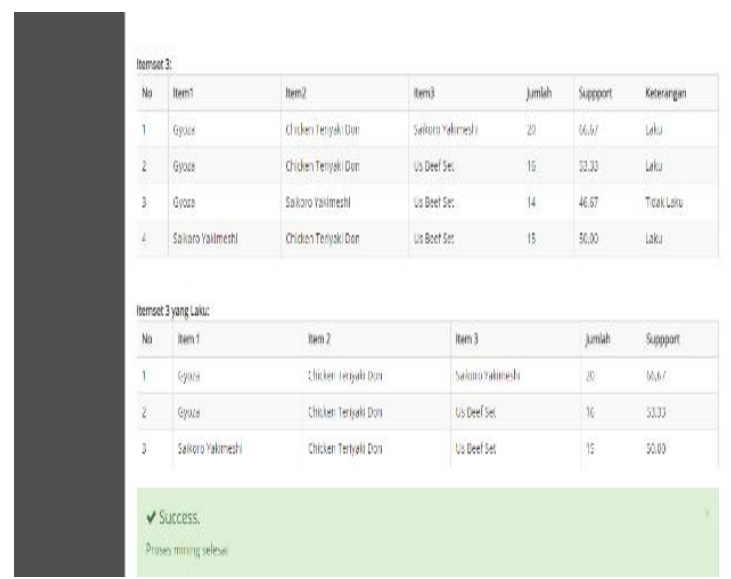

Figure 6. 
The result of the combination of three items in figure 6 support that exceed the threshold of 50\% there are three categories, namely Gyoza + Chicken Teriyaki Don + Saikoro Yakimeshi, Teriyaki Chicken Gyoza + Don + Us Beef Set and Saikoro Yakimeshi + Chicken Teriyaki Don + Us Beef Set.

Can be seen in Figure 7 is obtained following the rules of association.
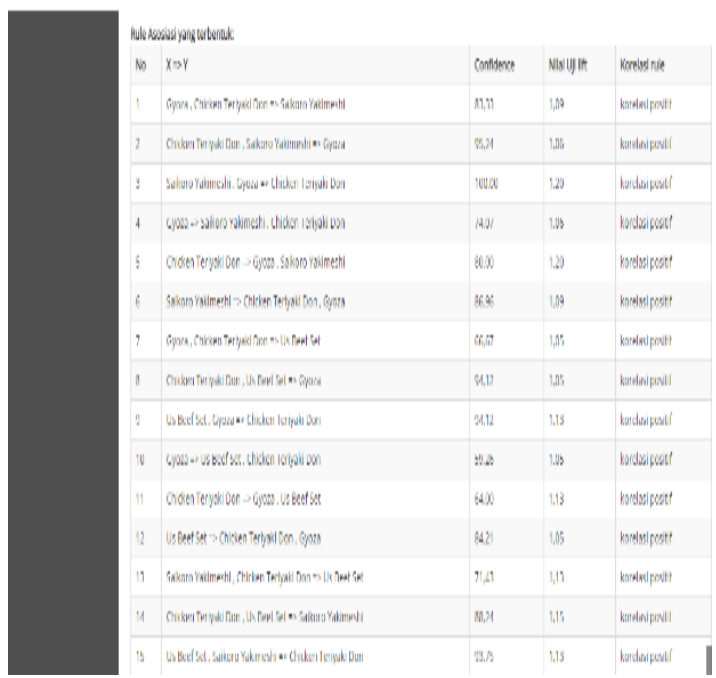

Figure 7.

of the rules of the association formed in Figure 7 generates a rule that if a customer ordered Gyoza Saikoro Yakimeshi and then would order Chicken Teriyaki Don with the highest confidence score of $100 \%$.

of the calculation process with Apriori algorithm in table 7 and the calculation by using a system built then the resulting comparison will be seen in Table 8 below.

Tests were also done by putting some value support to produce a wide range of categories of association rules:

1. Minimum support 10: generating a rule if a customer ordered the Chicken Teriyaki Don then be ordered Gyoza with confidence value of $96 \%$.

2. Minimum support 20: produce a rule that if a customer ordered the Chicken Teriyaki Don then be ordered gyoza and Saikoro Yakimeshi with $80 \%$ confidence value.

Table 8. Results of the calculations

\begin{tabular}{|c|c|c|}
\hline No. & Mechanical calculations & result \\
\hline 1 & Manual calculations with & If a customer \\
& ordered Gyoza \\
& Apriori algorithm & Saikoro \\
& & Yakimeshi and \\
& then would \\
& & order Chicken \\
& & Teriyaki Don \\
& & with the highest \\
& & confidence \\
& & score of $100 \%$. \\
& & \\
& & \\
& & \\
& &
\end{tabular}

\begin{tabular}{|c|c|c|}
\hline 2 & $\begin{array}{c}\text { Calculations with a system } \\
\text { built }\end{array}$ & $\begin{array}{c}\text { If a customer } \\
\text { ordered Gyoza } \\
\text { Saikoro } \\
\end{array}$ \\
& & Yakimeshi and \\
& then would \\
& order Chicken \\
& Teriyaki Don \\
& with the highest \\
& & confidence \\
& & score of $100 \%$. \\
& \\
& \\
& \\
& \\
\hline
\end{tabular}

\section{CONCLUSION}

Based on the results of the implementation of Apriori algorithm method with association rules on the sales transaction data in Spanish Fonzu Premium generate some rules that:

1. If a customer ordered Gyoza Saikoro Yakimeshi and then would order Chicken Teriyaki Don with the highest confidence score of $100 \%$.

2. If a customer ordered the Chicken Teriyaki Don and Saikoro Yakimeshi then be ordered Gyoza with confidence value of $95 \%$.

3. If a customer ordered a Us Beef Gyoza Set and then will order the Chicken Teriyaki Don with a confidence value of $94 \%$.

4. If a customer ordered the Chicken Teriyaki Don and Us Beef Gyoza Set will book with confidence value of $94 \%$.

5. If a customer ordered a Us Beef Set and Saikoro Yakimeshi then be ordered Chicken Teriyaki Don with a confidence value of $93 \%$.

And has been developed in the form of web-based applications. By using this application can simplify the managerial side in the prediction of the most frequently ordered menu and in demand by consumers and can identify linkages between menus often booked simultaneously.

\section{ACKNOWLEDGMENT}

This research was held on funds from national universities, namely competitive research in 2018. this research was the result of collaboration between lecturers and final year students.

\section{REFERENCES}

[1] Robi Yanto, Riri Khiriah, "Implementation of Data Mining Methods Apriori Algorithm In Determining Drug Purchasing Patterns", Vol.2, No.1, February 2015-April 2015 ISSN: 2354-5771.

[2] Della Sophia, Latitude Yuniar Banowosari, "Implementation Method Using Association Rules Apriori Algorithm On Sale Transaction Data In Waroeng Special Sambal", vol.22 No.1, April 2017.

[3] Ristianigrum, Sulastri. (2017) "Implementation of Data Mining Algorithm Using Apriori" syntax Proceedings, 2017. ISBN: 978-602-8557-20-7.

[4] Kennedi Tampubolon, Hoga Saragih, Bobby Reza, "Implementation of Data Mining Algorithm Apriori On Inventory System Health Tools", Vol. No. 1, October 2013 ISSN: 2339-210X. 
[5] Muhammad Haikal; "Implementation of Data Mining To Predict Results of the Sale of Goods In Store New Light Using Apriori Algorithm": The University of Nusantara PGRI Kediri; 12.1.03.02.0213.

[6] Agung Triayudi, Hervian, "On Credit Financing Level Measuring PT.Trihamas Finance Using Apriori Data Mining Algorithm", Journal of ProTekinfo Vol.4 August 2017. ISSN: 2406-7741.

[7] Maharani, Nelly Astuti, Natalia Silalahi, "Implementation of Data Mining For Layout settings Minimarket By Applying Association Rule", Vol.4 No.4, August 2017 ISSN: 2407-389X.

[8] Fajri, Akhmad Fikri, 2016, "Implementation of Apriori Algorithm in Determining Program Students Taken", Journal of Applied Science and Technology Research of Applied Science and Education V10.i2 (81-85), ISSN: 1979-9292, May 2016.

[9] Lismardiana, Herman Mawengkang, Erna Budhiarti Nababan, "Development of Apriori Algorithm To Penganbilan Decision", Vol. 4 No. 2 December 2015: 110-121.

[10] Agung Triayudi, Iskandar Fitri "Comparison of Parameter-Free Agglomerative Hierarchical Clustering Methods", ICIC Express Letters 12 (10), 973-980, 2018.

[11] Chhavi Rana, "A Study of Web Usage Mining Research
Tools", Volume: 03, Issue: 06 Pages: 1422-1429 (2012) ISSN: 0975-0290.

[12] Sanjeev Rao, Priyanka Gupta, "Implementing Improved Apriori Algorithm Over Data Mining Association Rule Algorithm", Vol.3, Issue 1, January- March 2012.

[13] Kaur, Manpreet, ShivaniKang, "Market Basket Analysis: Identify the changing trends of the market of data using association rule mining", International Conference on Computational Modeling and Security (CMS 2016) Procedia Computer Science 85 (2016) 78-85.

[14] Mohiuddin Khan A, Pradhan Sateesh K, Khaleel MA. Outlier Detection for Business Intelligence using Data Mining Techniques.International Journal of Computer Applications 2014: 106 (2): 28-31.

[15] Andrej Trnka. Market Basket Analysis with Data Mining Methods International Conference on Networking and Information Technology, 2010: 446-450.

[16] Senkul P., and S. Copy, Improving Quality in Web Usage Pattern Mining by Using Semantic Information, Knowledge and Information Systems, 1 (6), 2011, 400404.

[17] BS Kumar, and KV Rukmani, Implementation of Web Usage Mining APRIORI and FP Growth Using Algorithms, International Journal of Advanced Networking and applicatons, 1 (06), 2010, 400-404 